\title{
Spontaneous sphenoid sinus cerebrospinal fluid leak and meningoencephalocele - are they due to patent Sternberg's canal?
}

\author{
Magdalena Tomaszewska, Eliza Brożek-Mądry, Antoni Krzeski \\ Department of Otorhinolaryngology, Faculty of Medicine and Dentistry, Medical University of Warsaw, Warsaw, Poland
}

Videosurgery Miniinv 2015; 10 (2): 347-358

DOI: $10.5114 /$ wiitm.2014.47097

\begin{abstract}
Sternberg's canal is a congenital bony defect in the lateral wall of the sphenoid sinus. If it persists to adulthood, it may become a source of spontaneous cerebrospinal fluid leak (CSF) and meningoencephalocele. The aim of the study was to describe the authors' experience and review articles related to spontaneous sphenoid sinus CSF leaks and Sternberg's canal. We analysed patients managed surgically due to sphenoid sinus CSF leak and performed a PubMed database search. Two female patients with spontaneous CSF leak of sphenoid origin were found. Both patients underwent surgery with the endoscopic endonasal approach, and the defect was closed using the multi-layer technique. Twelve articles related to CSF leaks of sphenoid origin (due to Sternberg's canal) were found in the PubMed database. Lines of lesser resistance within sphenoid bone may underlie CSF leak pathology together with intracranial hypertension. The endoscopic transnasal approach to the sphenoid sinus is an excellent alternative to standard transcranial procedures.
\end{abstract}

Key words: Sternberg's canal, spontaneous cerebrospinal fluid leak, endoscopic endonasal approach, multilayer dural repair, sphenoid sinus meningoencephalocele.

\section{Introduction}

The term "spontaneous cerebrospinal fluid leak" has been applied to patients without previous trauma, surgery, malformation, tumor or radiation therapy [1, 2]. In comparison with other localizations, sphenoid sinus is a rare source of cerebrospinal fluid (CSF) leak [3]. However, spontaneous CSF leak may be more common in this localization than secondary CSF leak [2, 3].

Complicated ontogenesis of sphenoid bone may promote pathological bony defects within the sphenoid sinus wall. During embryological development, independent cartilaginous precursors are formed separately to become, after the ossification period, particular parts of the sphenoid bone: presphenoid (anterior sphenoid bone), basisphenoid (posterior sphenoid bone), orbitosphenoid (lesser wings), and alisphenoid (greater wings, lateral parts of the pterygoid process). Only the medial plate of the pterygoid process is built up by membranous ossification (Figure 1). The fusion of central sphenoid bone parts and lateral sphenoid bone parts separately takes place before birth. Of major importance is the fusion of central with lateral parts that occurs after birth. Only a weak cartilaginous connection between central and lateral parts has been found in neonates' bones. Thus, the fusion plane creates a line of lesser resistance within the sphenoid bone. Ossification of this cartilaginous connection starts anteriorly and progresses posteriorly [4-6]. Before final fusion, a small canal connecting the middle cranial fossa with the nasopharynx is created, called the lateral craniopha-

\section{Address for correspondence}

Eliza Brożek-Mądry MD, PhD, Department of Otorhinolaryngology, Division of Dentistry, Medical University of Warsaw, 19/25 Stepinska St, 00-739 Warsaw, Poland, phone: +48 609559 917, e-mail: elizabrozek@wp.pl 

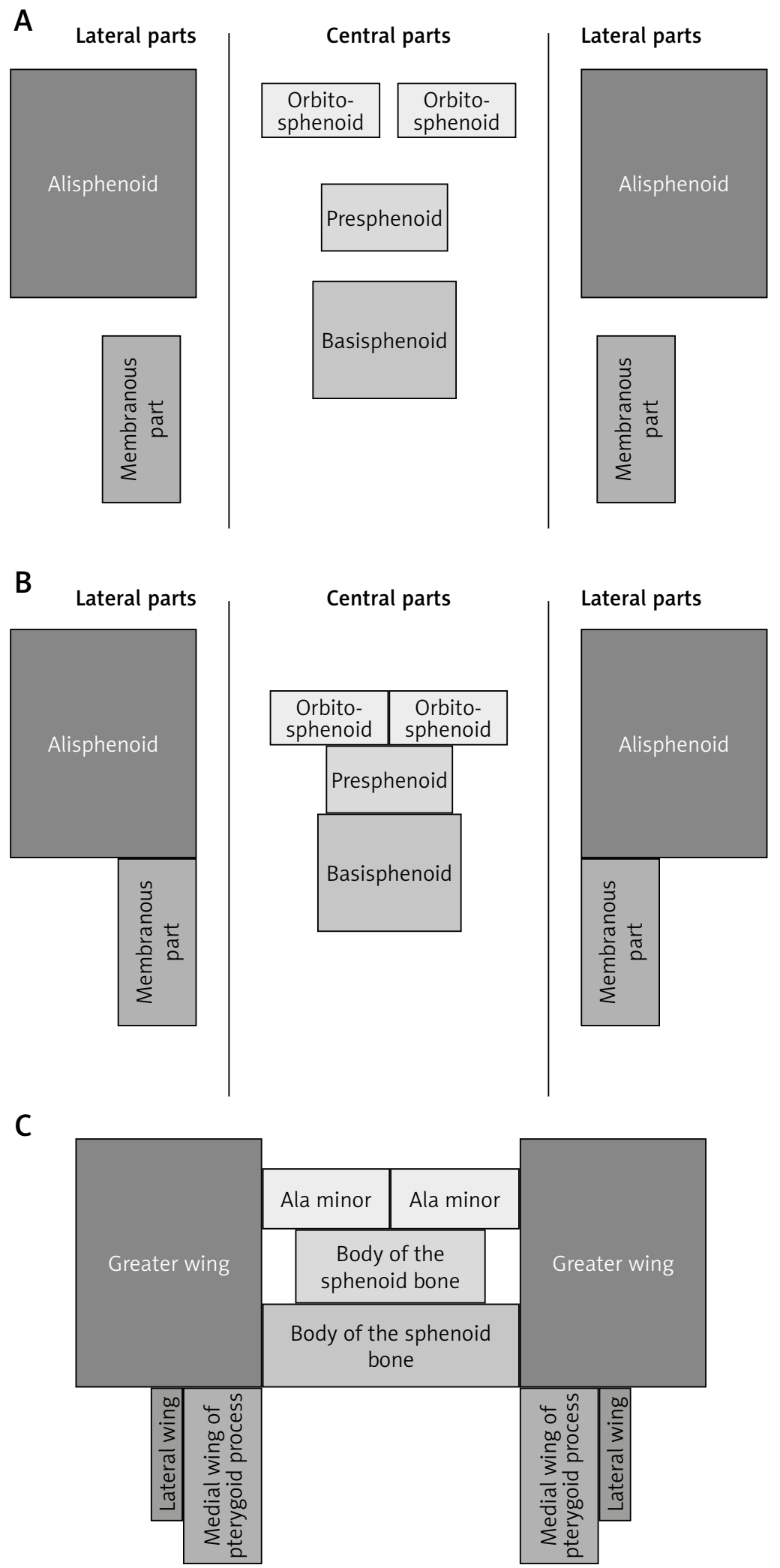

Figure 1. Sphenoid bone ontogenesis: A, B - prenatal period, C - postnatal period 
ryngeal canal. By definition, the lateral craniopharyngeal canal starts intracranially between the sphenoid bone body and the posterior roof of the lesser wing and goes downwards on the side of the sphenoid bone body into the nasopharynx, where it ends at the level of the vaginal process (near the vomerovaginal canal). Thereby, it goes exactly at the fusion plane between the central part and the lateral parts.

Presence of the lateral craniopharyngeal canal was discovered for the first time by Cruveilhier in 1877 , and 11 years later by Sternberg in 1888 [7, 8]. Over the last decade, most authors have used the term Sternberg's canal. Sternberg described constant presence of the canal in the skulls of 3-4 year old children. The ossification process continues up to the age of 10, until the canal is closed. Under unknown circumstances, Sternberg's canal may persist patent until adulthood (Photo 1). When the sphenoid sinus develops and reaches the fusion plane, Sternberg's canal may create a connection between the middle fossa and the sphenoid sinus, and thus become a potential source of CSF leak, meningoencephalocele or meningitis [9].

The aim of this study is to describe the authors' experience with spontaneous sphenoid sinus CSF leaks and meningoencephaloceles, and to review articles related to Sternberg's canal in the PubMed database.

\section{Case reports}

Patients with CSF leak due to sphenoid sinus pathology were identified in a retrospective review of medical records between 2000 and 2012. The study was approved by the Ethics Committee at the Medical University of Warsaw. All patients with a history of trauma, previous sinus or skull base surgery or radiotherapy were excluded. Clinical data of presenting symptoms, gender, age, and body mass index (BMI) were reviewed. The exact anatomic localization of the bony defect within the sphenoid sinus was obtained from available preoperative imaging studies and compared to those from operative reports. Histological examination data were reviewed, and the surgical approach, skull base reconstruction technique and final operative result were noted. During the follow-up period, patients were evaluated in endoscopic examination.

The authors searched the PubMed database with the phrases Sternberg's canal, lateral craniopharyngeal canal, sphenoid sinus encephalocele, and sphe-
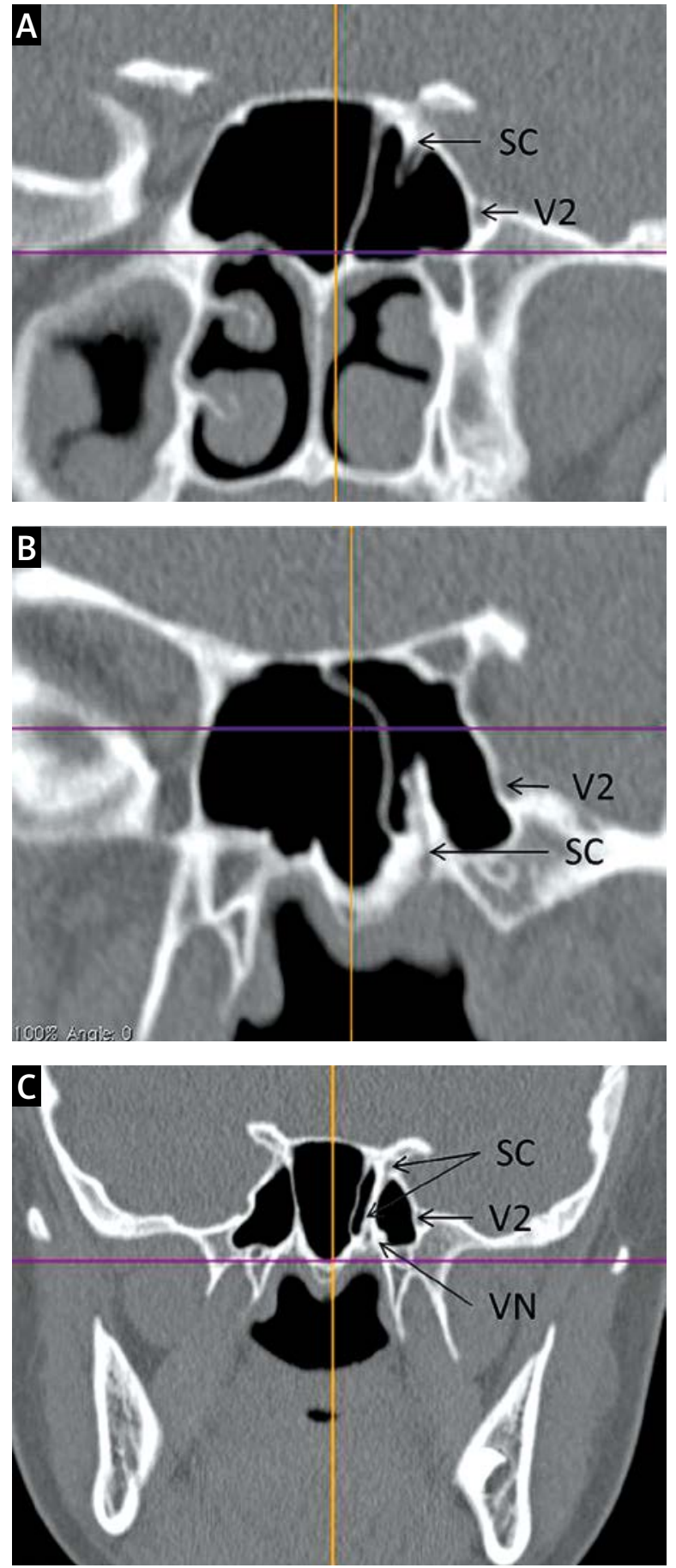

Photo 1 A-C. A 13-year-old patient with an accidentally found Sternberg's canal (SC)

V2 - Second branch of trigeminal nerve, VN - Vidian nerve.

noid sinus spontaneous CSF leak in an attempt to find and critically review all the described cases of sphenoid sinus spontaneous CSF leak due to persistent Sternberg's canal. 
Two patients with spontaneous CSF leak from the sphenoid sinus were identified in our records.

\section{Case 1}

A 66-year-old female patient, obese, suffered from long-lasting intermittent left-sided watery nasal discharge. There were no clinical signs of elevated intracranial pressure. The ENT examination revealed left-sided rhinorrhea. This was confirmed by biochemical tests of the albumin/glucose levels. Computed tomography (CT) scans were performed in coronal sections (Photo 2). They disclosed a roundshaped pathological lesion partially occupying the left sphenoid sinus. The lesion was connected with the lateral wall of the sinus. A coronal T1-weighted magnetic resonance imaging (MRI) of the brain clearly depicted cephalocele herniation through the floor of the middle cranial fossa into the left sphenoid sinus. Additionally, MRI revealed the presence of arachnoid cyst in the parietal region (Photo 3). There was no enlargement in ventricular size, nor an empty sella. The patient was operated on using the endoscopic approach, i.e. the transethmoidal-sphenoidal approach (TESA). The site of origin was confirmed on the lateral wall of the left sphenoid sinus. The lesion was cauterized and resected. The tissue sample was sent for histological examination. All of the mucosa and periosteum of the sphenoid sinus was removed carefully to denude the bone. We plugged

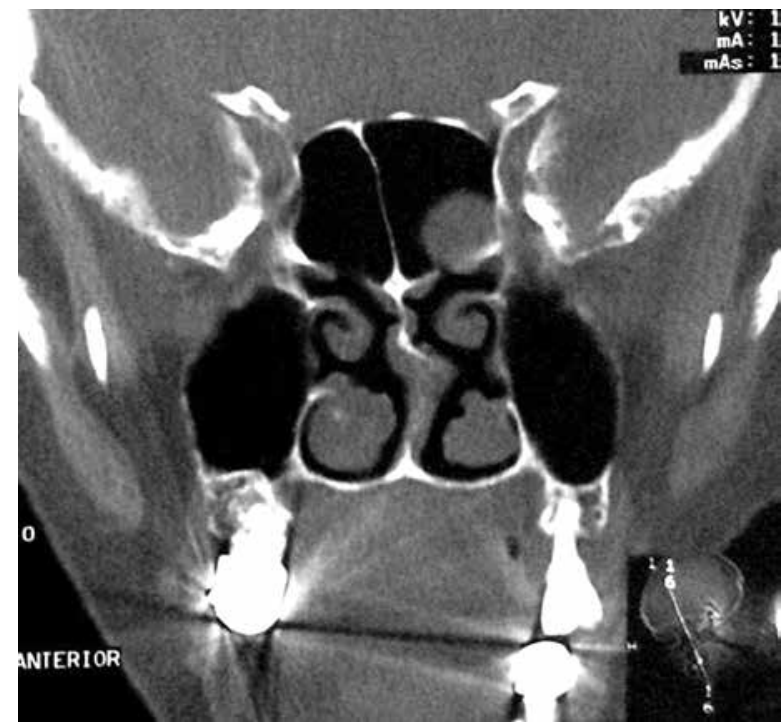

Photo 2. Case 1. CT scan with round shaped lesion situated within anterior portion of left sphenoid sinus the dehiscence in the middle fossa with abdominal fat before applying fascia lata and a mucoperiosteal free flap with the overly technique. Lumbar drainage was not used at the time of surgery. A histological examination confirmed the presence of brain tissue within the sample. The patient was followed up for 3 years without any suspicion of recurrence.

\section{Case 2}

A 72-year-old female patient, obese, suffered from long-lasting right-sided watery nasal discharge. There were no clinical signs of elevated intracranial pressure. The ENT examination revealed right-sided rhinorrhea, confirmed by biochemical tests of the albumin/glucose levels. High resolution coronal CT scans disclosed a highly pneumatized lateral recess of the sphenoid sinus that extended laterally to the foramen rotundum into the greater wings of the sphenoid bone (Photo 4). The lack of bone between the middle cranial fossa and the roof of the lateral recess was evident with a pathological mass protruding

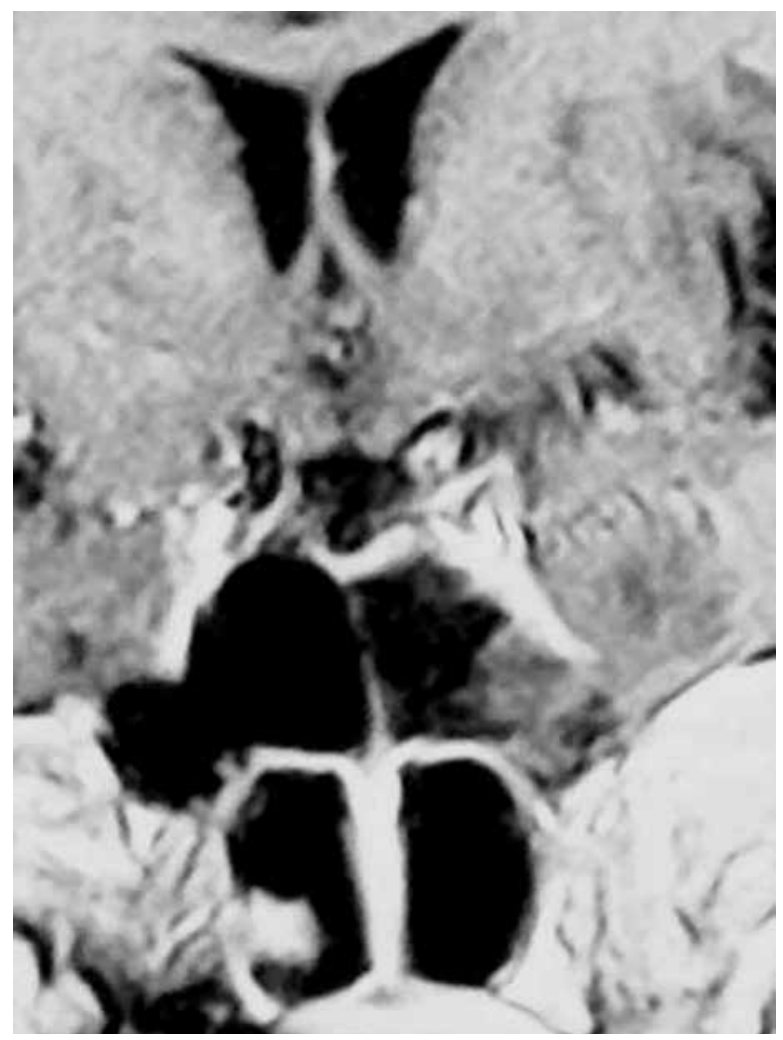

Photo 3. Case 1. Coronal T1 weighted MRI of the brain showing a pathological tissue herniation through the floor of the middle cranial fossa into the left sphenoid sinus 


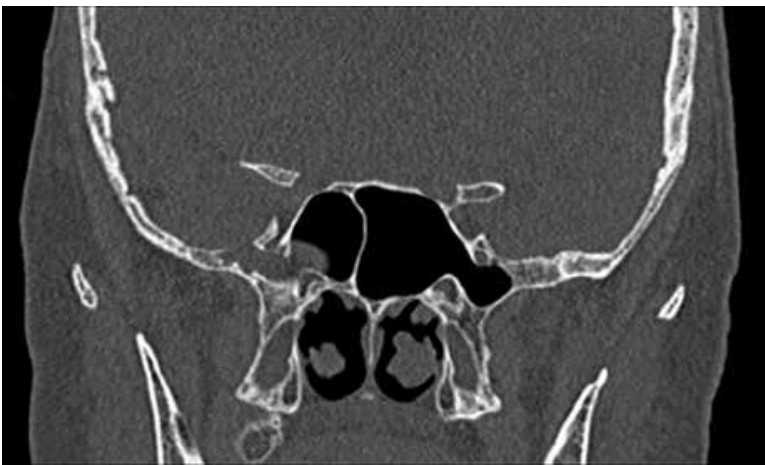

Photo 4. Case 2. HRCT showing highly pneumatized lateral recess, lack of bony border of the middle cranial fossa, pathological mass protruding into right sphenoid sinus

into the left sphenoid sinus. A coronal T2-weighted MRI of the brain depicted polycystic tissue herniation through the floor of the middle cranial fossa into the left lateral recess of the sphenoid sinus (Photo $5 \mathrm{~A}$ ). There was a partially empty sella on sagittal T2 MRI (Photo 5 B). Due to far lateral extension of the sphenoid sinus, the endoscopic transethmoidal-sphenoidal-pterygoidal approach (TESPA) was chosen as the surgical procedure. We began with a wide maxillary antrostomy followed by complete sphenoethmoidectomy performed in a standard manner. After that, an attempt to expose the posterior wall of the maxillary sinus was performed. The sphenopalatine artery was exposed and coagulated. The posterior wall of the maxillary sinus was then removed and the pterygopalatine fossa was entered. We carefully identified and coagulated the branches of the maxillary artery. The deeper neural structures of the pterygopalatine fossa were identified and transposed laterally and inferiorly to expose the base of the pterygoid process, which was then drilled away. We then entered the lateral recess of the sphenoid sinus. The V2 was localized and preserved. After having identified the leak, the encephalocele was cauterized and resected. Mucosa and periosteum around the defect were removed to denude the bone. A multilayer closure of the defect was performed. The first layer of abdominal fat followed by fascia lata was placed intracranially (underlay technique). The second layer of fat tissue and the last one, mucoperiosteum from the middle turbinate, were put into the sphenoid sinus using the overlay technique, and additionally fixed with fibrin glue. Lumbar drainage was not used at the time of surgery. The follow-up lasted 1 year with
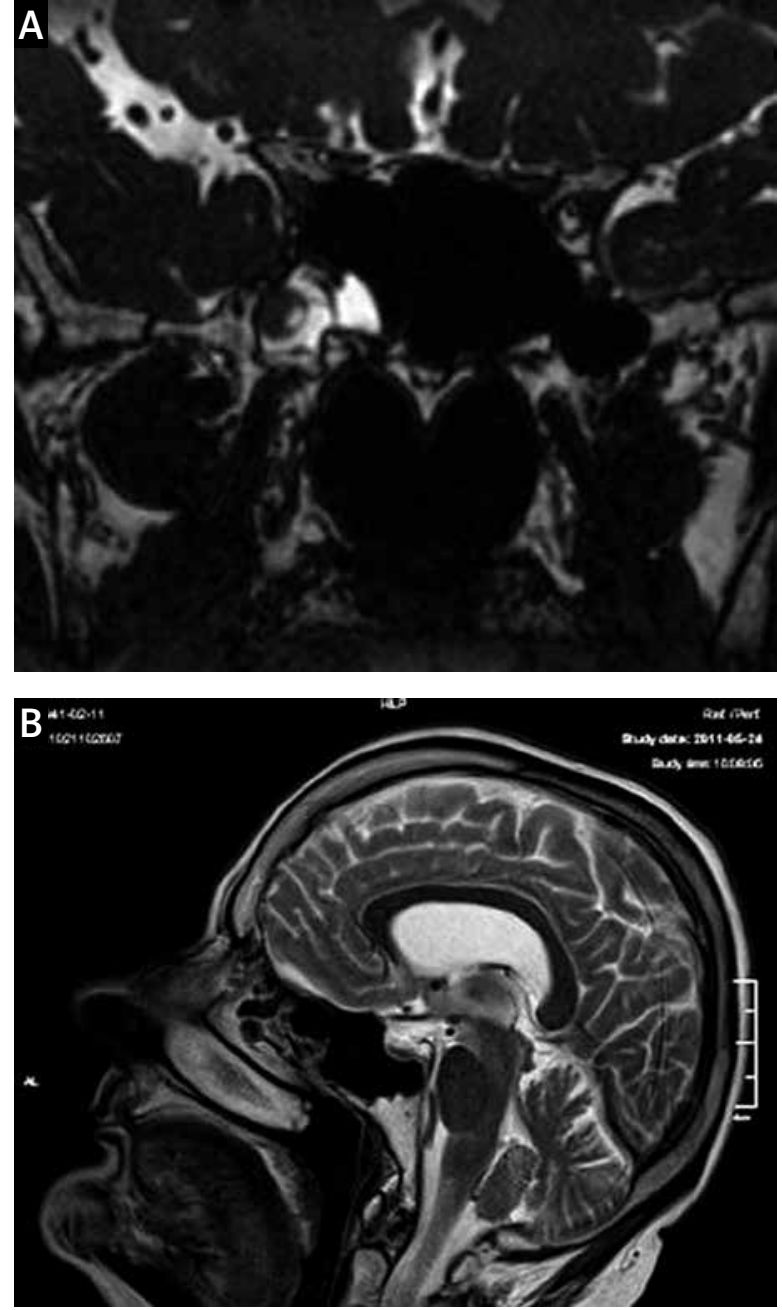

Photo 5. Case 2. A - Coronal T2 MRI revealing polycystic tissue herniation through floor of middle cranial fossa into highly pneumatized lateral recess of sphenoid sinus. B - Sagittal T2 $M R I$ revealing partially empty sella turcica

endoscopic examination of the nasal cavity being performed every 3 months. There were no signs of recurrence.

The authors found twelve articles devoted to Sternberg's canal (lateral craniopharyngeal canal) in the PubMed database. Eleven of them were clinical case series with 43 cases described overall (Table I). The last one was devoted to the use of radiological investigations to estimate the presence of Sternberg's canal.

\section{Discussion}

Nasal CSF leaks may arise from pathology of the anterior, middle and posterior cranial fossae. Their 


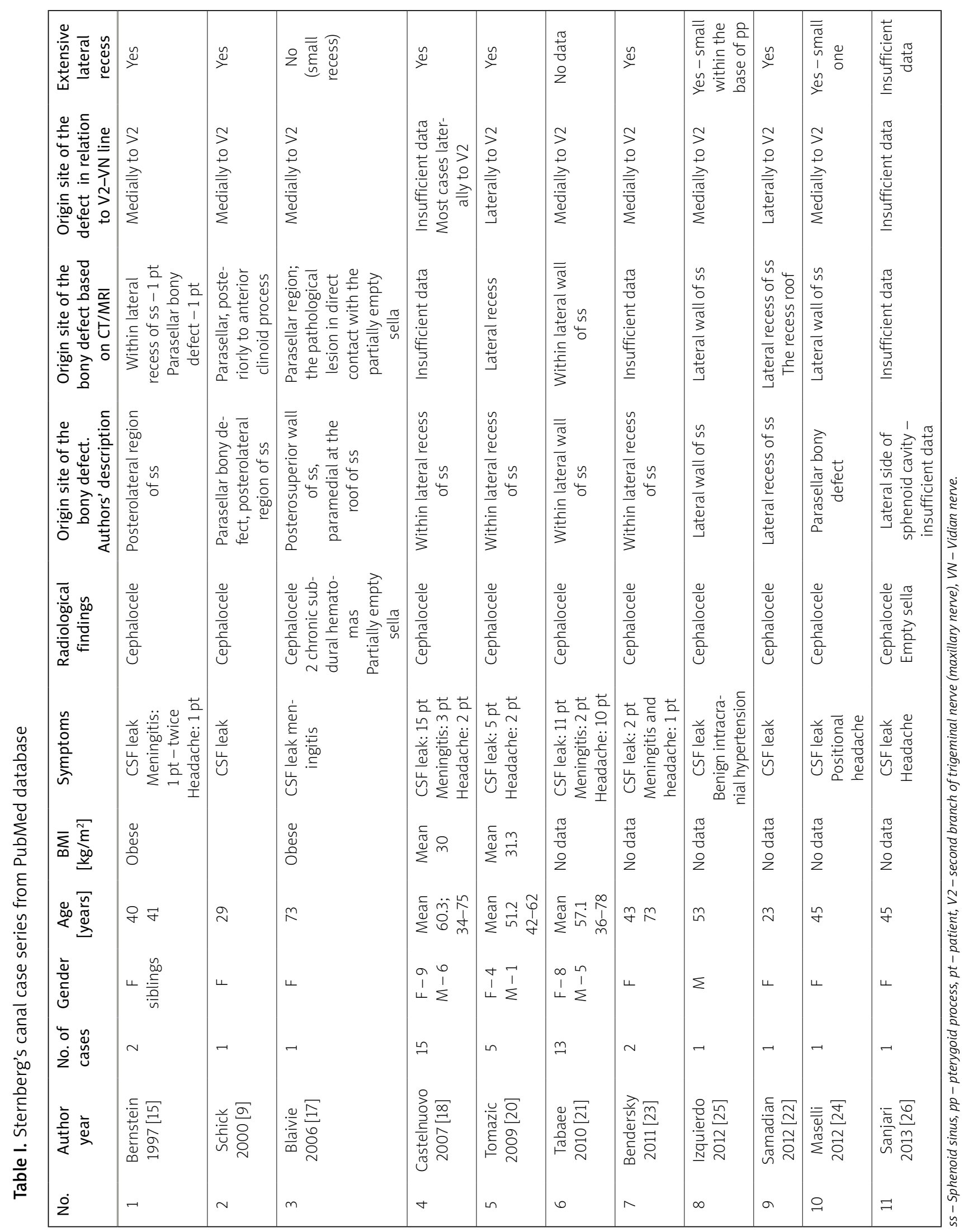


origin is either spontaneous or secondary due to different medical events, such as trauma or surgery. There is agreement among physicians, based on clinical data, that the most common site of CSF leak is the floor of the anterior cranial fossa, which communicates either with the sinuses (i.e. ethmoidal, frontal) or directly with the nasal cavity [3]. Most cases are of traumatic origin [3, 10]. Estimates of the spontaneous origin of CSF rhinorrhea range from $6 \%$ to $23 \%$ among all causes of CSF leaks [10-14]. During the last decade, more attention has been drawn to the sphenoid sinus as a potential source of spontaneous CSF leak and middle cranial fossa cephalocele. Recent data suggest that spontaneous sphenoid sinus leaks are even more frequent than secondary ones. Shetty et al. retrospectively reviewed 145 cases of CSF fistula (both spontaneous and secondary) and estimated that $10 \%$ of them involved the sphenoid sinus, and $7 \%$ of all cases were spontaneous leaks from the sphenoid sinus [3]. Schuknecht et al. described among 27 cases of spontaneous CSF rhinorrhea $46.4 \%$ cases of sphenoid origin [2]. Thereby, we hypothesize that there must be special anatomical or physiological conditions predisposing the sphenoid sinus to become a source of spontaneous CSF leak. When discussing these conditions, we should also take into account either congenital or acquired nature of that pathology. In accordance with the literature, the possible sites of sphenoidal osseodural defects are the upper roof of the lateral recess of the sphenoid sinus, the persistent Sternberg's canal (lateral craniopharyngeal canal), parasellar region, and sphenoid roof [2, 3, 9, 15-26]. In anatomic investigations, bony dehiscences were also described alongside the internal carotid artery groove as a result of pulsatile forces pushing against the lateral wall of the sphenoid sinus [27].

Sternberg's canal (lateral craniopharyngeal canal) has been recently proposed by many authors as an underlying factor related to sphenoid sinus spontaneous CSF leaks. There are two main anatomical requirements for the lateral craniopharyngeal canal to be considered a potential source of CSF leak. The first requirement involves ossification disturbances within the fusion planes of the sphenoid bone which allow the lateral craniopharyngeal canal to persist patent until adulthood. The second one is the presence of a sufficiently pneumatized sphenoid sinus. The formation of the sphenoid si- nus continues until the age of 20 . There is common agreement that the bone is reabsorbed under the influence of mucosa, and the process should stop at the edge of the sphenoid body, leaving a sheet of bone covering the sinus. When the pneumatization process reaches Sternberg's canal, the connection between the middle cranial fossa and the sphenoid sinus is created. Estimates on the incidence of persisting patent lateral craniopharyngeal canal range widely from $0.42 \%$ to $6.1 \%$ in anatomical cadaver studies of the adult population [8, 27-29]. Remnants of this canal, too small to allow communication between the sinus and intracranial cavity, were seen in $18.1-28.4 \%$ of half sphenoid bones [27, 29]. The newest data, based on high-resolution CT scans, do not confirm these numbers. Baranano et al. investigated 1000 high-resolution CT scans of sphenoid bones in an attempt to assess bony defects possibly representing Stenberg's canal [19]. They found only one defect consistent with the anatomical description of the canal's localization, which they claim should be located medially to V2 within the lateral wall of the sphenoid sinus. Moreover, the identified canal was smaller than the anatomic demonstration of the true canal.

The PubMed search related to Sternberg's canal revealed twelve articles (Table I). Bernstein et al. did not use the term Sternberg's canal, but he strongly suggests the congenital origin of the two described cases of cranial base defects; thus we decided to include the paper in the analysis [15]. Eleven articles were clinical case series, which describe a total of 43 patients with spontaneous sphenoid sinus CSF leak due to a patent lateral craniopharyngeal canal.

When analyzing the bony dehiscences referred to as Sternberg's canal, we noticed heterogeneous descriptions of them. The site of origin was depicted by different authors with terms such as: posterolateral region of the sphenoid sinus, posterosuperior wall of the sphenoid sinus, parasellar region, within the lateral recess, within the lateral wall and on the lateral side of the sphenoid cavity. According to different types of sphenoid pneumatization, all of these terms seem to be imprecise. Moreover, by definition Sternberg's canal starts intracranially between the sphenoid bone body and the posterior roof of the lesser wing and goes downwards on the side of the sphenoid body into the nasopharynx, where it ends at the level of the vaginal process (near the vomerovaginal canal). According to this anatomical de- 
scription, Baranano et al. claim that the canal has to be located medially to the superior orbital fissure, thus medially to the foramen rotundum and V2 [19]. Relying on this statement, 22 of the reviewed cases showed the defect localized medially to V2 (19 cases described on the lateral wall of the sinus; 3 cases in the parasellar region). On the other hand, Tomazic and Stammberger define the defect related to Sternberg's canal laterally to V2 (5 cases) [20]. Castelnuovo et al. also describe most of their cases laterally to V2 (in a study group of 15 patients) [18].

The question arises whether both localizations have a homogeneous origin. There is a lot of controversy about whether the lesions occurring laterally and medially to V2 are of the same origin and about the relation between the lateral recess leaks and Stemberg's canal. Extensive lateral pneumatization of the sphenoid sinus across the line connecting V2 and the Vidian nerve into the pterygoid process and/or greater wing creates the lateral recess of the sphenoid sinus. This anatomical variation of the sinus may promote thinning of the skull base between the middle cranial fossa and sinus cavity.

In 1977, Kaufman et al. proposed a theory of the acquired nature of nontraumatic, normal pressure CSF leaks [30]. The authors pointed out that the coincidence of anatomical and physiological factors has to be taken into account to explain the pathogenesis of this kind of leak. As the authors suggest, pneumatization of the sinuses along the skull base in conjunction with pulsatile forces and intermittently increased CSF pressure may erode the thin bone alongside the sinocranial border. Ommaya et al. suggest that the pressure of CSF in the arachnoid pouch could cause erosion of the thin sellar floor [1]. O'Connell advanced acquired nature of nontraumatic CSF rhinorrhoea due to a fistula in the lamina cribrosa over which he found a pulsating pocket of CSF [31]. A similar hypothesis is mentioned for sphenoid sinus leaks [2, 3, 19, 32, 33]. It is believed that extensive lateral pneumatization of the sphenoid sinus into the greater wings and pterygoid process, together with the presence of arachnoid villi pits in the bottom of the middle fossa, is capable of creating bony erosion over the course of many years. Patients with sphenoid spontaneous CSF leaks reveal higher incidence of extensive lateral pneumatization and the presence of arachnoid pits lateral to V2 when compared to patients without CSF leak (lateral recess 91-100\% vs. $23-35.3 \%$ and $63-100 \%$ vs. $0-23.4 \%$ arachnoid pits respectively) $[3,19]$.

Interestingly, all articles presenting cases related to Sternberg's canal revealed a spontaneous CSF leak together with cephalocele within the sphenoid sinus, protruding through relatively small bony defects. This observation is considered to be an indicator of acquired nature of the lateral recess defects [2, 34]. Other clinical features observed in lateral sphenoid leaks, such as the presence of an empty sella, female sex, middle age, and obesity, may suggest the role of attenuated CSF circulation/pressure as a potential risk factor [2, 32, 34-41] (Table I). Relations between spontaneous CSF leaks and cephaloceles within the sphenoid sinus and benign intracranial hypertension need further investigation.

Management of CSF leaks and meningoencephaloceles in the sphenoid sinus is debated by various specialists according to their experience. Differences are described in surgical approach, reconstruction methods and adjuvant strategies (lumbar drainage, image guidance, application of fluorescein). Among traditional, wide approaches, transcranial and transpalatal surgery have been discussed. Recently, due to technical development, endoscopic techniques have been favored instead of transcranial and transpalatal approaches.

Surgical treatment of CSF leaks in the lateral recess of the sphenoid sinus can be a surgical dilemma even for the most skilled surgeons because of the difficulties in gaining adequate access to this area [18]. Factors determining the choice of approach include the degree of lateral pneumatization of the sphenoid sinus, location and size of cephalocele, and ability to perform an adequate skull base repair through a given exposure [21].

In the past, transcranial approaches have been commonly used for surgical management of sphenoid sinus lateral recess pathology. They were performed through the pterional route or through the middle fossa (fronto-spheno-temporal approach) and were used to repair encephaloceles within the lateral recess of the sphenoid sinus. Fronto-spheno-temporal craniotomy provides a good access for exploration of the middle cranial fossa floor. Disadvantages of this approach include a large external incision, temporal lobe retraction, intensive care unit monitoring, and seizures afterwards. However, in transcranial surgery the burden of central nervous system infection is thought to be smaller than in endoscopic 
Table II. Surgical treatment of analyzed case series

\begin{tabular}{|c|c|c|c|c|c|c|c|}
\hline No. & $\begin{array}{l}\text { Author } \\
\text { year }\end{array}$ & $\begin{array}{l}\text { No. of } \\
\text { cases }\end{array}$ & Surgical approach & $\begin{array}{c}\text { Skull base reconstruction } \\
\text { technique }\end{array}$ & $\begin{array}{l}\text { Lumbar } \\
\text { drainage }\end{array}$ & Complications & Recurrence \\
\hline 1 & $\begin{array}{l}\text { Bernstein } \\
1997[15]\end{array}$ & 2 & $\begin{array}{l}\text { External ethmoid- } \\
\text { ectomy (Lynch } \\
\text { incision) }\end{array}$ & $\begin{array}{c}\text { Fascia }+ \text { abdominal fat } \\
\text { obliteration }\end{array}$ & Yes & No & $1 \mathrm{pt}$ \\
\hline 2 & $\begin{array}{l}\text { Schick } \\
2000[9]\end{array}$ & 1 & $\begin{array}{l}\text { Transcranial pteri- } \\
\text { onal (fronto-tempo- } \\
\text { ral) approach }\end{array}$ & $\begin{array}{l}\text { Abdominal fat (bottle } \\
\text { neck fashion) }\end{array}$ & No data & No & No \\
\hline 3 & $\begin{array}{c}\text { Blaivie } \\
2006[17]\end{array}$ & 1 & $\begin{array}{l}\text { Endoscopic } \\
\text { endonasal: } \\
\text { TS }\end{array}$ & $\begin{array}{c}\text { Septal cartilage, du- } \\
\text { raplasty + abdominal fat } \\
\text { obliteration + } \\
2^{\text {nd }} \text { layer of septal carti- } \\
\text { lage }\end{array}$ & No & No & No \\
\hline 4 & $\begin{array}{l}\text { Castel- } \\
\text { nuovo } \\
2007[18]\end{array}$ & 15 & $\begin{array}{c}\text { Endoscopic } \\
\text { endonasal: } \\
\text { TS }-6 \text { pt } \\
\text { TESPA - } 9 \text { pt }\end{array}$ & $\begin{array}{c}\text { Obliteration with abdomi- } \\
\text { nal fat }-6 \mathrm{pt} \\
\text { Multilayer: } \\
\text { Middle turbinate bone } \\
\text { and mucoperiosteum, } \\
\text { nasal septum cartilage, } \\
\text { mucoperiosteum; dural } \\
\text { substitute }\end{array}$ & No & & No \\
\hline 5 & $\begin{array}{l}\text { Tomazic } \\
2009[20]\end{array}$ & 5 & $\begin{array}{l}\text { Endoscopic } \\
\text { endonasal: } \\
\text { TESA - } 2 \text { pt } \\
\text { TESPA - } 3 \text { pt }\end{array}$ & $\begin{array}{l}\text { Multilayer } \\
\text { Abdominal fat in "bath- } \\
\text { plug" fashion } \\
\text { Fascia lata overlay; fibrin } \\
\text { glue }\end{array}$ & No & $\begin{array}{c}\text { Meningitis - } \\
1 \text { pt } \\
\text { Brain abscess } \\
-1 \text { pt }\end{array}$ & $\begin{array}{l}2 \mathrm{pt} \\
\text { Endoscopic } \\
\text { revision } \\
\text { surgery }\end{array}$ \\
\hline 6 & $\begin{array}{l}\text { Tabaee } \\
2010[21]\end{array}$ & 13 & $\begin{array}{l}\text { Endoscopic } \\
\text { endonasal: } \\
\text { 1. TS } 5 \\
\text { 2. TESA } 5 \\
\text { 3. TESPA } 3\end{array}$ & $\begin{array}{c}\text { Multilayer } \\
\text { Bone, fascia lata or } \\
\text { temporalis, mucoperios- } \\
\text { teal flap, abdominal fat, } \\
\text { cartilage } \\
\text { Dural substitute - differ- } \\
\text { ent combinations }\end{array}$ & 8 pt-yes & $\begin{array}{l}\text { Meningitis - } \\
1 \text { pt } \\
\text { Facial pares- } \\
\text { thesia-1 pt }\end{array}$ & $\begin{array}{l}1 \mathrm{pt}-\text { endo- } \\
\text { scopic revision } \\
\text { surgery } \\
1 \text { pt }- \text { spon- } \\
\text { taneously } \\
\text { stopped }\end{array}$ \\
\hline 7 & $\begin{array}{l}\text { Bendersky } \\
2011[23]\end{array}$ & 2 & $\begin{array}{c}\text { Transcranial } \\
\text { (fronto-temporal) } \\
1 \text { pt (after } 3 \times \text { endo- } \\
\text { scopic approach) } \\
2 \text { pt (after } 1 \times \text { endo- } \\
\text { scopic approach) }\end{array}$ & $\begin{array}{c}\text { Multilayer } \\
2 \text { layers of dural graft } \\
\text { bone }\end{array}$ & No data & no & $\begin{array}{l}\text { No recurrence } \\
\text { after transcra- } \\
\text { nial approach }\end{array}$ \\
\hline 8 & $\begin{array}{l}\text { Izquierdo } \\
2012 \\
\text { Abstract [25] }\end{array}$ & 1 & $\begin{array}{l}\text { Endoscopic } \\
\text { TESPA }\end{array}$ & No data in English & $\begin{array}{l}\text { No data } \\
\text { in English }\end{array}$ & & $\begin{array}{l}\text { No data in } \\
\text { English }\end{array}$ \\
\hline 9 & $\begin{array}{l}\text { Samadian } \\
2012[22]\end{array}$ & 1 & Transcranial & $\begin{array}{c}\text { Multilayer } \\
\text { Cranial bone, temporalis } \\
\text { fascia }\end{array}$ & No data & No & No \\
\hline 10 & $\begin{array}{c}\text { Maselli } \\
2012[24]\end{array}$ & 1 & $\begin{array}{l}\text { Endoscopic } \\
\text { endonasal: } \\
\text { TS }\end{array}$ & $\begin{array}{c}\text { Multilayer } \\
\text { Abdominal fat "bottle- } \\
\text { neck" fusion + muscle + } \\
\text { fibrin glue }\end{array}$ & No data & No & No \\
\hline 11 & $\begin{array}{l}\text { Sanjari } \\
2013[26]\end{array}$ & 1 & $\begin{array}{l}\text { Endoscopic } \\
\text { endonasal }\end{array}$ & $\begin{array}{l}\text { Fat + pediculated mucosal } \\
\text { flap }\end{array}$ & $\begin{array}{l}\text { None } \\
\text { after } \\
\text { surgery }\end{array}$ & No & $\begin{array}{l}\text { Twice } 1 \text { week } \\
\text { and } 1 \text { year } \\
\text { after surgery- } \\
\text { lumbar drain- } \\
\text { age applied }\end{array}$ \\
\hline
\end{tabular}


surgery because it allows the surgeon to reach the defect through a more sterile operative field [42].

Among endoscopic techniques, three modalities have been applied according to the localization of changes with respect to the midline: the transsphenoidal approach (transnasal approach), the TESA and TESPA [18, 20, 21, 43]. The CSF leaks close to the midline can be managed with the transsphenoidal approach or transethmoidal-sphenoidal approach. Extensive lateral pneumatization of the sphenoid sinus and lateral recess CSF leak require either the TESA or the TESPA.

The transsphenoidal approach involves enlargement of the natural sphenoid ostium in the superior meatus and creation of a common cavity incorporating both ostia with removal of the posterior portion of the nasal septum. Angled endoscopes inserted on the contralateral side allow improved visualization of the lateral wall of the sphenoid sinus. Skull base reconstruction methods involve different strategies of plugging the dehiscence. Prior reports described obliteration of the sinus with a fat graft without a specific skull base reconstruction $[18,21]$. This option can be used in small sphenoid cavities where accurate removal of mucosa can be achieved, but unfortunately CSF leaks usually arise in well-pneumatized bones. The relapse of CSF leak and mucocele formation associated with this method has led surgeons to widening of the corridor (TESA, TESPA) to obtain appropriate visualization of the osseodural defects, enabling an efficacious skull base reconstruction.

The transethmoidal-sphenoidal approach is required in cases of lateral pneumatization of the sphenoid sinus. It involves anterior and posterior ethmoidectomy with a large sphenoidectomy. This may be combined with a transsphenoidal approach providing additional lateral exposure [21]. For lesions localized far laterally, TESPA is considered a preferable method. It allows better control over the lateral recess of the sphenoid sinus while sparing important anatomic structures and minimizing surgical mortality and morbidity [18, 43]. The surgeon reaches the lateral recess through the posterior wall of the maxillary sinus and pterygopalatine fossa. Opening the pterygopalatine fossa accesses the sphenopalatine and maxillary arteries, V2 and Vidian nerve. Careful cauterization of the arteries and preservation of the nerves should always be attempted [20].
Mucosa and periosteum around the defect have to be removed to create an effective receptor site for grafts. Reconstruction techniques of the skull base combine underlay and overlay techniques (multilayer techniques) with both auto- and allogenic materials [18, 20, 21] (Table II).

The advantages of the endoscopic approach include less traumatic character, without a large external incision, and temporal lobe retraction, thus minimizing brain manipulation [18, 42, 44, 45]. The disadvantages of endoscopic techniques involve their challenging character, especially when the TESPA approach is applied. A potential risk for significant complications includes persistent CSF leak, neurovascular injuries and meningitis. Castelnuovo et al. advise using a four-hand technique when possible [18].

The first of our patients was closed with TESA performed 10 years prior to the second one (TESPA). The time gap between those two let us gain more experience followed by acquiring more sophisticated tools to perform this type of surgical procedure.

\section{Conclusions}

Cephaloceles within the sinus and extensive lateral recess are typical radiological findings in cases of sphenoid sinus CSF leaks. Complex ontogenesis of sphenoid bone which creates the lines of lesser resistance within the bone may be responsible for this phenomenon. Taking into account all controversies about the origins of spontaneous sphenoid sinus CSF leak, we can hypothesize that developmental conditions such as Sternberg's canal and extensive lateral pneumatization of the sphenoid sinus together with pathological conditions involving intracranial hypertension and arachnoid pits underlie the pathology.

Over the last three decades, the approach has become less invasive due to application of endoscopic transnasal techniques, leaving patients without large scars and with good results. A small sphenoid sinus (i.e. without extensive lateral pneumatization) requires the transethmoidal sphenoidal approach, whereas lateral extension of the sinus should lead the surgeon to apply the TESPA.

\section{Conflict of interest}

The authors declare no conflict of interest. 


\section{References}

1. Ommaya AK, Di Chiro G, Baldwin M, Pennybacker JB. Non traumatic cerebrospinal fluid rhhinorrhoea. J Neurol Neurosurg Psychiatry 1968; 31: 214-25.

2. Schuknecht B, Simmen D, Briner HR, Holzmann D. Nontraumatic skull base defects with sponataneous CSF rhinorrhea and arachnoid herniation: imaging findings and correlation with endoscopic sinus surgery in 27 patients. Am J Neuroradiol 2008; 29: 542-9.

3. Shetty PG, Shroff MM, Fatterpekar GM, et al. A retrospective analysis of spontaneous sphenoid sinus fistula: MR and CT findings. Am J Neuroradiol 2000; 21: 337-42.

4. Van Alyea OE. Sphenoid sinus. Anatomic study with consideration of the clinical significance of the structured characteristics of the sphenoid sinus. Arch Otolaryngol 1941; 34: 225-53.

5. Starck D. Embiologie. Thieme, Suttgart 1975; 582-603.

6. Bochenek A. Reicher M. Anatomia człowieka [Polish]. PZWL, Warsaw 2008; vol I: 334-55.

7. Cruveilhier J. Traite d'Anatomie Descriptive. 5th ed. Paris 1877.

8. Sternberg M. Ein bisher noch nicht beschriebener Kanal im KeiIbein des Menschen. Anat Anz 1888; 3: 784-5.

9. Schick B, Brors D, Prescher A. Sternberg's canal - cause of congenital sphenoidal meningocele. Eur Arch Otolaryngol 2000; 257: 430-2.

10. Stone JA, Castillo M, Neelon B, Mukherji SK. Evaluation of CSF leaks: high resolution CT compared with contrast-enhansed CT and radionuclide cisternography. AJNR Am J Neyroradiol 1999; 20: 706-12.

11. Wolf G, Greistorfer K, Stammberger H. Endoscopic detection of cerebrospinal fluid fistulas with fluorescence technique. Report of experiences with over 925 cases. Laryngorhinootologie 1997; 76: 588-94.

12. Simmen D, Bischoff T, Schuknecht B. Experiences with assessment of frontobasal defects, a diagnostic concept. Laryngorhinootologie 1997; 76: 583-7.

13. Tuntiyatorn L, Laothammatas J. Evaluation of MR cisternography in diagnosis of cerebrospinal fluid fistula. J Med Assoc Thai 2004; 87: 1471-6.

14. Lindstrom DR, Toohill RJ, Loehrl TH, Smith TL. Management of cerebrospinal fluid rhinorrhoea: the Medical College of Wisconsin experience. Laryngoscope 2004; 114: 969-74.

15. Bernstein JM, Roland T, Persky MS. Sphenoidal cranial base defects in siblings presentig with cerebrospinal fluid Leak. Skull Base Surg 1997; 7: 193-7.

16. Bolger WE, Osenbach R. Endoscopic transpterygoid approach to the lateral sphenoid recess. Ear Nose Throat J 1999; 78: 36-46.

17. Blaivie C, Lequeoux T, Kampouridis S, et al. Congenital transsphenoidal meningocele: case report and review of the literature. Am J Otolaryngol Head Neck Surg 2006; 27: 422-4.

18. Castelnuovo P, Dallan I, Pistochini A, et al. Endonasal endoscopic repair of Sternberg's canal cerebrospinal fluid leaks. Laryngoscope 2007; 117: 345-9.

19. Baranano CF, Cure J, Palmer JN, Woodworth BA. Sternberg's canal: fact or fiction? Am J Rhinol Allergy 2009; 23: 1676-71.

20. Tomazic PV, Stammberger H. Spontaneous CSF-leaks and meningoencephaloceles in sphenoid sinus by persisting Sternberg's canal. Rhinology 2009; 47: 369-74.
21. Tabaee A, Anand VK, Cappabianca P, et al. Endoscopic management of spontaneous meningoencephalocele of the lateral sphenoid sinus. J Neurosurg 2010; 112: 1070-7.

22. Samadian M, Moghaddasi H, Vazirnezami M, et al. Transcranial approach for spontaneous CSF rhinorrhhea due to Sternberg's canal intrasphenoidal meningoencephalocele: case report and review of the literature. Turk Neurosurg 2012; 22: 242-5.

23. Bendersky DC, Landriel FA, Ajler PM, et al. Sternberg's canal as a cause of encephalocele within the lateral recess of the sphenoid sinus: a report of two cases. Surg Neurol Int 2011; 2: 171.

24. Maselli G, Ricci A, Galzio RJ. Endoscope-assisted trans-sphenoidal approach for treatment of Sternberg's canal. J Korean Neurosurg Soc 2012; 52: 555-7.

25. Izquierdo MR, Martin MC, Caballer TL. Asociatción entre fístula de líquido cefalorraquídeo y persistencia del canal de Sternberg: coincidencia o causa? Acta Otolaryngologica Espaniola 2012; 63: 144-6.

26. Sanjari R, Mortazavi SA, Amiri RS, et al. Intrasphenoidal meningo-encephalocele: report of two rare cases and review of literature. Surg Neurol Int 2013; 4: 5.

27. Hooper AC. Sphenoidal defects - a possible cause of cerebrospinal fluid rhinorrhoea. J Neurol Neurosurg Psychiat 1971; 34: 739-42.

28. Arey LB. The craniopharyngeal canal reviewed and reinterpreted. Anat Rec 1950; 106: 1-16.

29. Radoievitch S, Jovanovitch S. Le canal embryonnaire de Cruveihier-Sternberg (canalis crabiopharyngeus lateralis) et ses vestiges chez l'homme adulte. Rev Laryng 1956; 77: 223-32.

30. Kaufman B, Yonas H, Witt RJ, Miller CF. Acquired middle cranial fossa fistulas: normal pressure and nontraumatic origin. Neurosurgery 1979; 5: 466-72.

31. O'Connell JEA. Primary sponataneous cerebrospinal fluid rhinorrhoea. J Neurol Neurosurg Psychiat 1964; 27: 241-6.

32. Woodworth BA, Palmer JN. Spontaneous cerebrospinal fluid leaks. Curr Opin Otolaryngol Haed Neck Surg 2009; 17: 59-65.

33. Tóth M, Selivanova O, Schaefer S, Mann W. Spontaneous cerebrospinal fluid rhinorrhoea: a clinical and anatomical study. Laryngoscope 2010; 120: 1724-9.

34. Schlosser RJ, Bolger WE. Nasal cerebrospinal fluid leaks: critical review and surgical considerations. Laryngoscope 2004; 114: 255-65.

35. Schlosser RJ, Bolger WE. Significance of empty sella in cerebrospinal fluid leaks. Otolaryngol Head Neck Surg 2003; 128: 32-8.

36. Schlosser RJ, Bolger WE. Spontaneous nasal cerebrospinal fluid leaks and empty sella syndrome: a clinical association. Am J Rhinol 2003; 17: 91-6.

37. Schlosser RJ, Woodworth BA, Wilensky EM, et al. Spontaneous cerebrospinal fluid leaks: a variant of benign intracranial hypertension. Ann Otol Rhinol Laryngol 2006; 115: 495-500.

38. Suryadevara AC, Fattal M, Woods Cl. Nontraumatic cerebrospinal fluid rhinorrhea as a result of pseudotumor cerebri. Am J Otolaryngol 2007; 28: 242-6.

39. Wise SK, Schlosser RJ. Evaluation of spontaneous nasal cerebrospinal fluid leaks. Curr Opin Otolaryngol Head Neck Surg 2007; 15: 28-34.

40. Silver RI, Moonis G, Schlosser RJ, et al. Radiografic signs of eleviated intracranial pressure in idiopathic cerebrospinal fluid 
leaks: a possible presentation of idiopathic intracranial hypertension. Am J Rhinol 2007; 21: 257-61.

41. Woodrworth BA, Prrince A, Chiu AG, et al. Sponataneous CSF leaks: a paradigm for definitive repair and management of intracranial hypertension. Otolaryngol Head Neck Surg 2008; 138: 715-20.

42. Bendersky DC, Landriel FA, Ajler PM, et al. Sternberg's canal as a cause of encephalocele within the lateral recess of the sphenoid sinus: a report of two cases. Surg Neurol Int 2011; 2: 171.

43. Bolger WE. Endoscopic transpterygoid approach to the latera recess: surgical approach and clinical experience. Otolaryngol Head Neck Surg 2005; 133: 20-6.

44. Lai SY, Kennedy DW, Bolger WE. Sphenoid encephaloceles: disease management and identification of lesions within the lateral recess of the sphenoid sinus. Laryngoscope 2012; 112 1800-5.

45. Okhawa T, Nakao U, Uematsu Y, Itakura T. Temporal lobe encephalocele in the lateral recess of the sphenoid sinus presenting with intraventricular tension pneumocephalus. Skull Base 2010; 20: 481-6.

Received: 28.05.2014, accepted: 1.09.2014 